\title{
Pengembangan Produk Tempat Sampah Penghancur Plastik Berbasis Green Technology
}

\author{
Deyorizky Setyo Nugroho ${ }^{1}$, Farra Nabila Murti ${ }^{1}$, Max Dewar Rivero ${ }^{1}$, Muhammad Noviandy ${ }^{1}$, Siti \\ Nurlelyza Trisaid ${ }^{1}$, Aprilia Tri Purwandari ${ }^{1}$, Seto Bayu Ismoyo ${ }^{1}$, Niken Parwati ${ }^{*}$ \\ ${ }^{1}$ Program Studi Teknik Industri, Fakultas Sains dan Teknologi, Universitas Al Azhar Indonesia, Komplek \\ Masjid Agung Al Azhar, Jalan Sisingamangaraja, Kebayoran Baru, Jakarta Selatan 12110
}

Penulis untuk Korespondensi/E-mail: niken.parwati@gmail.com

Abstrak - Inovasi merupakan aspek kunci yang mendorong suatu perusahaan semakin berkembang dan tetap bertahan dalam ketatnya persaingan di pasar. Seiringan dengan perkembangan teknologi yang revolusioner, menimbulkan adanya kebutuhan akan produk-produk dengan kemampuan yang mutakhir, oleh karena itu dibutuhan pola pikir yang kreatif dan berorientasi pada kreativitas bagi para perusahaan untuk tetap mempertahankan kedudukannya di persaingan pasar. Dalam upaya menghasilkan produk yang inovatif dan berkualitas tinggi, diperlukan perencanaan dan pengembangan produk yang komprehensif, selain itu juga diharapkan memiliki manfaat yang berkelanjutan dan bermanfaat bagi kelestarian lingkungan. Salah satu orientasi yang ditujukan pada perusahaan saat ini ialah mengembangkan Green Technology yang merujuk pada pembangunan dan aplikasi produk, peralatan serta sistem untuk memelihara alam sekitar dan meminimumkan dampak kerusakan lingkungan yang diakibatkan oleh manusia. Pada penelitian ini, dilakukan perencanaan dan pengembangan produk tempat sampah penghancur plastik ramah lingkungan bertenaga mekanik, dengan sensor elektrik yang mampu mendeteksi ketinggian sampah agar tidak menumpuk. Alur penelitian dilakukan mulai dari pencarian dan pengumpulan ide produk, penyaringan ide produk yang feasible dan berpotensi menguntungkan, pembuatan prototipe produk, hingga analisis ekonomi dari produk yang akan dikembangkan. Tempat sampah penghancur sampah yang ramah lingkungan ini diberi nama Trade (Trash Destroyer).

Abstract - Innovation is a key aspect that encourages a company to grow and stay afloat in the tight competition in the market. In tandem with revolutionary technological developments, there is a need for products with cutting edge capabilities, therefore a creative, creativity-oriented mindset is required for companies to maintain their position in the marketplace. To be able to produce innovative and high quality products, comprehensive product planning and development is required, but it is also expected to have sustainable and beneficial benefits for environmental sustainability. One of the orientations aimed at companies today is to develop Green Technology which refers to the development and application of products, equipment and systems to maintain the natural surroundings and nature and minimize or minimize negative impressions rather than human activities. This study carries out the planning and development of an environmentally friendly, mechanical-powered, plastic crushing trash bin that is equipped with electric sensors which is capable of detecting the height of waste to prevent trash accumulation. The flow of research is carried out starting from the search and collection of product ideas, filtering feasible and potentially profitable product ideas, making product prototypes, to economic analysis of the products to be developed. This environmentally friendly trash dumpster is named Trade (Trash Destroyer).

Keywords - Green Technology, Planning and Development, Trade 


\section{PENDAHULUAN}

$\mathrm{P}$ enumpukan sampah merupakan salah satu faktor krusial yang menyebabkan terjadinya polusi tanah. Salah satu jenis sampah yang berkontribusi besar dalam polusi ialah limbah plastik, hal ini dikarenakan sifat kimiawi dari senyawa plastik yang tidak dapat diuraikan secara alamiah. Adapun bila dapat terurai, sampah plastik membutuhkan waktu bertahun-tahun lamanya untuk bisa diuraikan ke materi organiknya. Proses penguraian sampah biasanya dilakukan dengan cara membakarnya, pembakaran sampah ini tak hanya berkontribusi ke polusi tanah, namun ke polusi udara karena menimbulkan emisi gas-gas berbahaya ke udara. Oleh karena itu pada penelitian ini, diusulkan gagasan untuk mengembangkan suatu produk tempat sampah yang mampu membantu menguraikan sampah plastik, yakni bernama Trade (Trash Destroyer) yang diinstalasi dengan mesin penghancur didalamnya, yang dapat menghancurkan sampah agar tidak menumpuk dan menyebabkan polusi tanah. Dengan menghancurkan sampah menjadi kepingan kecil, diharapkan mampu membantu dalam mendaur ulang sampah plastik, untuk selanjutnya di proses kembali menjadi bijih plastik. Selain dilengkapi dengan alat penghancur, Trade juga memiliki sensor elektrik yang otomatis akan menyala untuk mengindikasikan ketinggian sampah agar tidak menumpuk dan bisa diambil untuk didaur ulang. Dalam penelitian Sistem Pengembangan Produk Trade, dilakukan proses perencanaan dan pengembangan produk melalui tahapan-tahapan penting seperti QFD (Quality Function Deployment) untuk mentranslasikan kebutuhan konsumen menjadi spesifikasi teknis, dan melakukan penyebaran kuesioner untuk mengetahui kebutuhan dan keinginan konsumen di pasar, selanjutnya dilakukan juga analisis ekonomi untuk menentukan apakah proyek pengembangan produk Trade layak dilakukan atau tidak, hingga akhirnya mencapai tahapan proses pembuatan prototype alpha Trade yang merupakan artifak asli dari sketsa yang sudah memiliki fitur dan kegunaan produk yang akan diluncurkan.

\section{TINJAUAN PUSTAKA}

\section{Green Technology}

Ruang lingkup dari green technology adalah teknologi sumber alam hijau, bangunan hijau, nanoteknologi hijau, dan alamtologi. Konsep penerapan teknologi hijau diterapkan dalam kehidupan manusia untuk keberlangsungan. Keberlangsungan adalah upaya untuk memenuhi kebutuhan masyarakat secara terus menerus pada masa depan tanpa merusak atau menghabiskan sumber daya alam. Penghematan sumber daya alam salah satunya dengan inovasi. Inovasi adalah upaya untuk mengembangkan alternatif teknologi yang ramah lingkungan guna memenuhi kebutuhan manusia tanpa merusak lingkungan [1]

\section{Sistem Pengembangan Produk}

Sistem pengembangan produk adalah upaya perusahaan untuk senantiasa menciptakan produkproduk baru, serta memperbaiki atau memodifikasi produk-produk lama, agar dapat selalu memenuhi tuntutan pasar dan selera konsumen. Kegiatan pengembangan produk tidak dapat dipisahkan dari konsep daur hidup produk. Setiap produk mengalami suatu siklus (daur) hidup tertentu mulai dari saat dirancang, diproduksi, diterjunkan ke pasar, kemudian melewati tahap-tahap perkenalan, tahap puncak, tahap kematangan atau kejenuhan [2].

\section{Fase Pengembangan Produk}

Enam fase dalam proses pengembangan produk secara umum adalah:

0 . Perencanaan

sebagai 'zerofase' karena kcgiatan ini mendahului persetujuan proyek dan proses peluncuran pengembangan produk aktual.

1. Pengembangan konsep

Pada fase pengembangan konsep, kebutuhan pasar target diidentifikasi, alternatif konsepkonsep produk dibangkitkan dan dievaluasi, dan satu atau lebih konsep dipilih untuk pengembangan dan percobaan lebih jauh.

2. Perancangan Tingkatan Sistem: Fase perancangan tingkatan sistem mencakup definisi arsitektur produk dan uraian produk menjadi subsistem-subsistem serta komponenkomponen.

3. Perancangan Detail

Fase perancangan detail mencakup spesifikasi lengkap dari bentuk, material, dan toleransitoleransi dari seluruh komponen unik pada produk dan identifikasi seluruh komponen standar yang dibeli dari pemasok.

4. Pengujian dan Perbaikan

Fase pengujian dan perbaikan melibatkan konstruksi dan evaluasi dari bermacam-macam versi produksi awal produk. Prototipe awal (alpha) biasanya dibuat dengan menggunakan komponen-komponen dengan bentuk dan jenis material pada produksi sesungguhnya, namun 
tidak memerlukan proses pabrikasi dengan proses yang sama dengan yang dilakukan pada produksi sesungguhnya. Prototipe (alpha) diuji untuk menentukan apakah produk akan bekerja sesuai dengan yang direncanakan dan apakah produk memenuhi kebutuhan kepuasan konsumen utama.

Prototipe berikutnya (beta) biasanya dibuat dengan komponen-komponen yang dibutuhkan pada produksi namun tidak dirakit dengan menggunakan proses perakitan akhir seperti pada perakitan sesungguhnya.

Prototipe beta dievaluasi secara internal dan juga diuji oleh konsumen dengan menggunakannya secara langsung. Sasaran dari prototipe beta biasanya adalah untuk menjawab pertanyaan mengenai kinerja dan keandalan dalam rangka mengidentifikasi kebutuhan perubahan-perubahan secara teknik untuk produk akhir.

5. Produksi awal

Pada fase produksi awal, produk dibuat dengan menggunakan sistem produksi yang sesungguhnya. Tujuan dari produksi awal ini adalah untuk melatih tenaga kerja dalam memecahkan permasalahan yang mungkin timbul pada proses produksi sesungguhnya.

Adapun fase dalam pengembangan produk menurut Ulrich \& Eppinger digambarkan pada Gambar 1 [3].

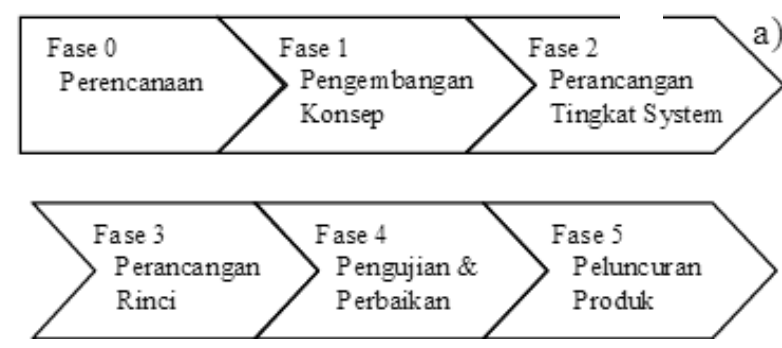

Gambar 1. Fase Pengembangan Produk

Inti dari pengembangan produk terletak pada fase pengembangan konsep karena pada fase ini dibutuhkan lebih banyak koordinasi dibandingkan dengan fase lainnya. Adapun kegiatan-kegiatan yang dilakukan pada fase pengembangan konsep berdasarkan Ulrich \& Eppinger dapat dilihat pada Gambar 2.

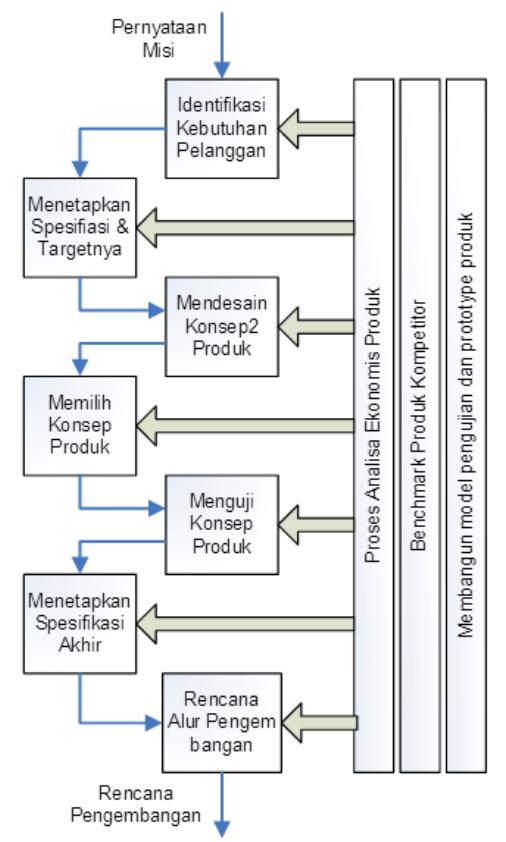

Gambar 2. Fase Pengembangan Produk

\section{Spesifikasi Produk}

Spesifikasi produk adalah variabel-variabel yang menjelaskan tentang hal-hal yang harus dilakukan oleh sebuah produk. Beberapa perusahaan mengunakan istilah "kebutuhan produk" atau "karakteristik engineering". Perusahaan lain memberi istilah "spesifikasi" atau "spesifikasi teknis" untuk menjelaskan variabel desain utama dari suatu produk.

\section{Arsitektur Produk}

Arsitektur produk adalah penugasan elemen elemen fungsional dari produk terhadap kumpulkan bangunan fisik. Tujuan arsitektur produk adalah menguraikan komponen fisik dasar dari produk, apa fungsi masing - masing komponen, dan interface seperti apa yang digunakan untuk peralatan lainnya. Keputusan mengenai arsitektur produk memberi kesempatan kepada tim, individual, dan atau pemasok untuk mengerjakan detail rancangan dan pengujian komponen, sehingga pegembangan bagian - bagian yang berbeda dari produk dapat dilakukan secara serempak [4]. Arsitektur produk adalah skema dimana elemen-elemen fungsional produk dibagi menjadi potongan (chunk) fisik dan dimana chunk berinteraksi. Chunk adalah kesatuan dari elemen fisik produk (part, komponen, subrakitan) yang mengimplementasikan fungsi produk. Tujuan dari arsitektur produk menguraikan komponen fisik dasar dari produk, apa yang harus dilakukan 
komponen tersebut dan seperti apa penghubung (interface) yang digunakan untuk peralatan lainnya. Output dari arsitektur produk adalah perkiraan rancangan geometri dari produk, penjelasan mengenai chunk-chunk utama, dokumentasi interaksi penting antar chunk. Arsitektur produk ditetapkan pada tahap pengembangan konsep, secara informal melalui sketsa, diagram-diagram fungsi dan prototipe awal dan pada tahap perancangan tingkat sistem.

\section{Harga Pokok Penjualan}

Harga Pokok Penjualan adalah semua biaya yang muncul dalam rangka menghasilkan suatu produk hingga produk tersebut siap dijual. dengan bahasa sederhana, Harga Pokok Penjualan yang biasa disingkat HPP merupakan biaya yang dikeluarkan dalam suatu proses produksi barang dan jasa yang dapat dihubungkan secara langsung dengan aktivitas prosess yang membuat produk barang dan jasa siap jual [5].

\section{METODOLOGI PENELITIAN}

Dalam konteks perencanaan dan pengembangan produk Trade, penelitian dilakukan mulai dari melakukan riset pasar untuk mengidentifikasi customer needs dari produk yang akan dikembangkan, hingga tahapan melangsungkan analisis kelayakan investasi daripada pengembangan produk Trade ini. Berikut diilustrasikan flowchart alur penelitian yang telah disusun secara sistematis:

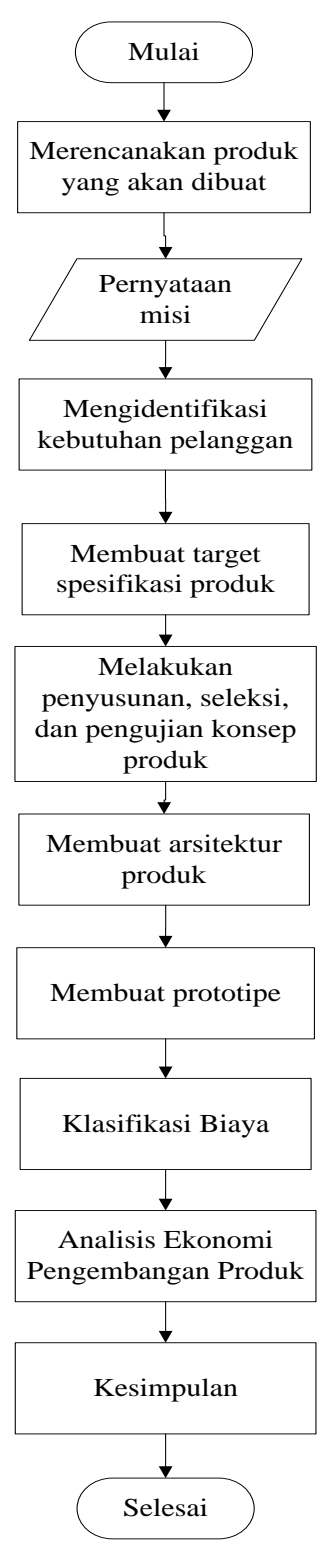

Gambar 3. Diagram Alir Penelitian

\section{HASIL DAN PEMBAHASAN}

\section{Pernyataan Misi}

Dalam melakukan pengembangan suatu produk kita perlu memiliki pernyataan misi (mission statement). Pernyataan misi adalah arah dari suatu pengembangan produk. Pernyataan misi Pada pengembangan produk ini dapat dilihat pada Tabel 1.

Tabel 1. Pernyataan Misi Produk

\begin{tabular}{cl}
\hline \multicolumn{1}{c}{ Case } & \multicolumn{1}{c}{$\begin{array}{c}\text { Tempat Sampah } \\
\text { Penghancur Plastik }\end{array}$} \\
\hline \multirow{3}{*}{ Uraian Produk } & $\begin{array}{l}\text { 1. Tempat sampah yang } \\
\text { mampu } \\
\text { menghancurkan/mencacah } \\
\text { sampah plastik }\end{array}$ \\
\hline
\end{tabular}




\begin{tabular}{|c|c|}
\hline Case & $\begin{array}{c}\text { Tempat Sampah } \\
\text { Penghancur Plastik }\end{array}$ \\
\hline & $\begin{array}{l}\text { 2. Berfungsi sebagai tempat } \\
\text { sampah yang mampu } \\
\text { membantu dalam mendaur } \\
\text { ulang sampah plastik, yang } \\
\text { kemudian dapat diproses } \\
\text { kembali menjadi bijih } \\
\text { plastik } \\
\text { 3. Dengan menggunakan } \\
\text { sensor untuk mendeteksi } \\
\text { plastik hasil pencacahan } \\
\text { yang dapat memberikan } \\
\text { isyarat bahwa sampah } \\
\text { tersebut harus segera di } \\
\text { keluarkan dari tempat } \\
\text { sampah }\end{array}$ \\
\hline $\begin{array}{l}\text { Sasaran Bisnis } \\
\text { Utama }\end{array}$ & $\begin{array}{l}\text { Menjadi tempat sampah } \\
\text { penghasil plastik pertama } \\
\text { untuk memudahkan } \\
\text { menguraikan sampah } \\
\text { plastik yang sulit terurai } \\
\text { sehingga plastik menjadi } \\
\text { lebih mudah untuk di daur } \\
\text { ulang. } \\
\text { Membantu dalam demo } \\
\text { atau kampanye go green }\end{array}$ \\
\hline $\begin{array}{l}\text { Primary } \\
\text { Market }\end{array}$ & $\begin{array}{l}\text { Seluruh elemen masyarakat } \\
\text { yang masih menggunakan } \\
\text { air minum dalam kemasan }\end{array}$ \\
\hline $\begin{array}{l}\text { Secondary } \\
\text { Market }\end{array}$ & $\begin{array}{l}\text { Restoran cepat saji yang } \\
\text { menggunakan air minum } \\
\text { dalam kemasan, dinas } \\
\text { kebersihan pemerintah } \\
\text { daerah }\end{array}$ \\
\hline $\begin{array}{l}\text { Assumption \& } \\
\text { Constraints }\end{array}$ & $\begin{array}{l}\text { Menggunakan gerakan } \\
\text { kinetik manual sehingga } \\
\text { tidak full otomatis dalam } \\
\text { memproses pencacahan } \\
\text { plastik } \\
\text { Menggunakan sensor jadi } \\
\text { ada kemungkinan error } \\
\text { Desain tempat sampah yang } \\
\text { masih belum optimal }\end{array}$ \\
\hline Stakeholders & $\begin{array}{l}\text { Investor } \\
\text { Bagian Produksi } \\
\text { Teknisi } \\
\text { Penjual atau distributor } \\
\text { Pembeli atau pengguna }\end{array}$ \\
\hline
\end{tabular}

\section{Identifikasi Kebutuhan Konsumen}

Dalam melakukan perencanaan pengembangan suatu produk terlebih dahulu dilangsungkan riset pasar yang gunanya untuk mengidentifikasi kebutuhan konsumen. Riset pemasaran produk dapat diawali dengan melakukan penyebaran prakuesioner. Pada pengembangan produk tempat sampah penghancur plastik diberlakukan penyebaran pra-kuesioner yang ditujukan untuk mengenalkan produk ke masyarakat luas dan mengetahui akan ketertarikan terhadap produk dan kebutuhan yang sebenarnya ada pada konsumen, pra-kuesioner disebarkan kepada 10 orang. Selain dilakukannya penyebaran pra-kuesioner, setelah mendapatkan feedback dari penyebaran prakuesioner, kuesioner ini selanjutnya disebarkan kepada 30 orang responden yang meliputi kalangan mahasiswa, pekerja, maupun ibu rumah tangga, dengan jumlah butir pertanyaan sebanyak 25 . Pada konteks penyebaran kuesioner ini diambil 5 aspek dari Dimensi Kualitas Garvin sebagai objek penilaian yang meliputi performance, features, reliability, aesthetic, dan conformance. Selanjutnya dilakukan uji validitas dan reliabilitas terhadap data yang diperoleh. Hasilnya adalah 21 dari 25 butir pertanyaan dinyatakan valid dan handal (reliable). Adapun variabel-variabel yang digunakan dalam identifikasi kebutuhan konsumen dikategorikan ke dalam matriks customer needs yang ditunjukkan pada Tabel 2.

Tabel 2. Variabel Kebutuhan Konsumen

\begin{tabular}{|c|c|}
\hline $\begin{array}{c}\text { Need } \\
\text { Number }\end{array}$ & Needs \\
\hline 1 & $\begin{array}{c}\text { Tombol otomatis penghancur } \\
\text { sampah }\end{array}$ \\
\hline 2 & $\begin{array}{l}\text { Pemberian sensor untuk } \\
\text { mengindikasi volume penampung }\end{array}$ \\
\hline 3 & Dilengkapi mesin yang tidak bising \\
\hline 4 & Desain dengan bentuk menarik \\
\hline 5 & Material yang kokoh \\
\hline 6 & $\begin{array}{l}\text { Desain dengan berbagai ukuran } \\
\text { Desain luas penampang dengan }\end{array}$ \\
\hline 7 & $\begin{array}{l}\text { berbagai ukuran } \\
\text { Tempat sampah Trade mudah dilepas }\end{array}$ \\
\hline 8 & saat diperbaiki \\
\hline 9 & $\begin{array}{l}\text { Tempat sampah dapat mati secara } \\
\text { otomatis bila sampah sudah terurai }\end{array}$ \\
\hline 10 & Mudah untuk dibersihkan \\
\hline 11 & $\begin{array}{c}\text { Tempat sampah Trade mudah untuk } \\
\text { digunakan }\end{array}$ \\
\hline 12 & $\begin{array}{l}\text { Perlu adanya perawatan dan } \\
\text { pembersihan }\end{array}$ \\
\hline 13 & $\begin{array}{l}\text { Memiliki panduan untuk perbaikan } \\
\text { dan pemeliharaan produk } \\
\text { Jasa perawatan cepat dan tidak }\end{array}$ \\
\hline 14 & berbelit-belit \\
\hline 15 & $\begin{array}{l}\text { Mampu menghancurkan sampah } \\
\text { plastik dengan waktu yang efisien } \\
\text { Luas penampang mampu }\end{array}$ \\
\hline 16 & mempengaruhi output sampah \\
\hline 17 & $\begin{array}{c}\text { Material bersifat tahan lama, masa } \\
\text { pakai yang lebih panjang } \\
\text { Prosedur pembelian mudah dan }\end{array}$ \\
\hline 18 & sesuai dengan permintaan \\
\hline
\end{tabular}




\begin{tabular}{|c|c|}
\hline $\begin{array}{c}\text { Need } \\
\text { Number }\end{array}$ & Needs \\
\hline 19 & $\begin{array}{c}\text { Jasa perawatan tersedia di berbagai } \\
\text { daerah }\end{array}$ \\
\hline 20 & $\begin{array}{c}\text { Desain dapat disesuaikan dengan } \\
\text { keinginan pembeli }\end{array}$ \\
\hline 21 & $\begin{array}{c}\text { Dapat diletakkan didalam ruangan } \\
\text { maupun didalam ruangan }\end{array}$ \\
\hline
\end{tabular}

\section{Target Spesifikasi Produk}

Spesifikasi produk merupakan serangkaian deskripsi yang memberikan informasi tentang detail produk yang tepat dan terukur. Adapun hasil dari spesifikasi akhirproduk yang akan dikembangkan dapat dilihat pada Tabel 3.

Tabel 3. Spesifikasi Akhir

\begin{tabular}{cllll}
\hline No & \multicolumn{1}{c}{ Need } & Metric & Unit & \multicolumn{1}{c}{ Value } \\
\hline 1 & $3,5,17$ & Material & Subject & $\begin{array}{l}\text { Stainless } \\
\text { Steel } \\
\end{array}$ \\
$\begin{array}{l}1,2,9,11,15, \\
16\end{array}$ & Fungsional & Subject & $\begin{array}{l}\text { Sensor } \\
\text { Indikasi }\end{array}$ \\
\hline
\end{tabular}

\begin{tabular}{|c|c|c|c|c|}
\hline No & Need & Metric & Unit & Value \\
\hline & & & & $\begin{array}{l}\text { Level } \\
\text { Sampah }\end{array}$ \\
\hline 3 & 5,17 & $\begin{array}{l}\text { Ketahanan } \\
\text { Produk }\end{array}$ & Tahun & $>5$ tahun \\
\hline 4 & $\begin{array}{l}4,6,7,8,10 \\
20,21\end{array}$ & Desain & Subject & Custom \\
\hline 5 & $\begin{array}{l}12,13,14,18, \\
19\end{array}$ & $\begin{array}{l}\text { Serviceabili } \\
\text { ty }\end{array}$ & Subject & Sedang \\
\hline
\end{tabular}

\section{Penyusunan, Seleksi, dan Pengujian Konsep}

Tahapan dalam pengembangan produk yang selanjutnya dilaksanakan adalah penyusunan konsep dengan melakukan klasifikasi terhadap konsep-konsep produk. Terdapat lima pilihan konsep dari hasil kombinasi konsep, yang diilustrasikan pada Gambar 4 dimana akan pemilihan konsep berdasarkan aspek-aspek pertimbangan yang meliputi konsep, material, fungsional, ketahanan produk, desain, dan serviceability

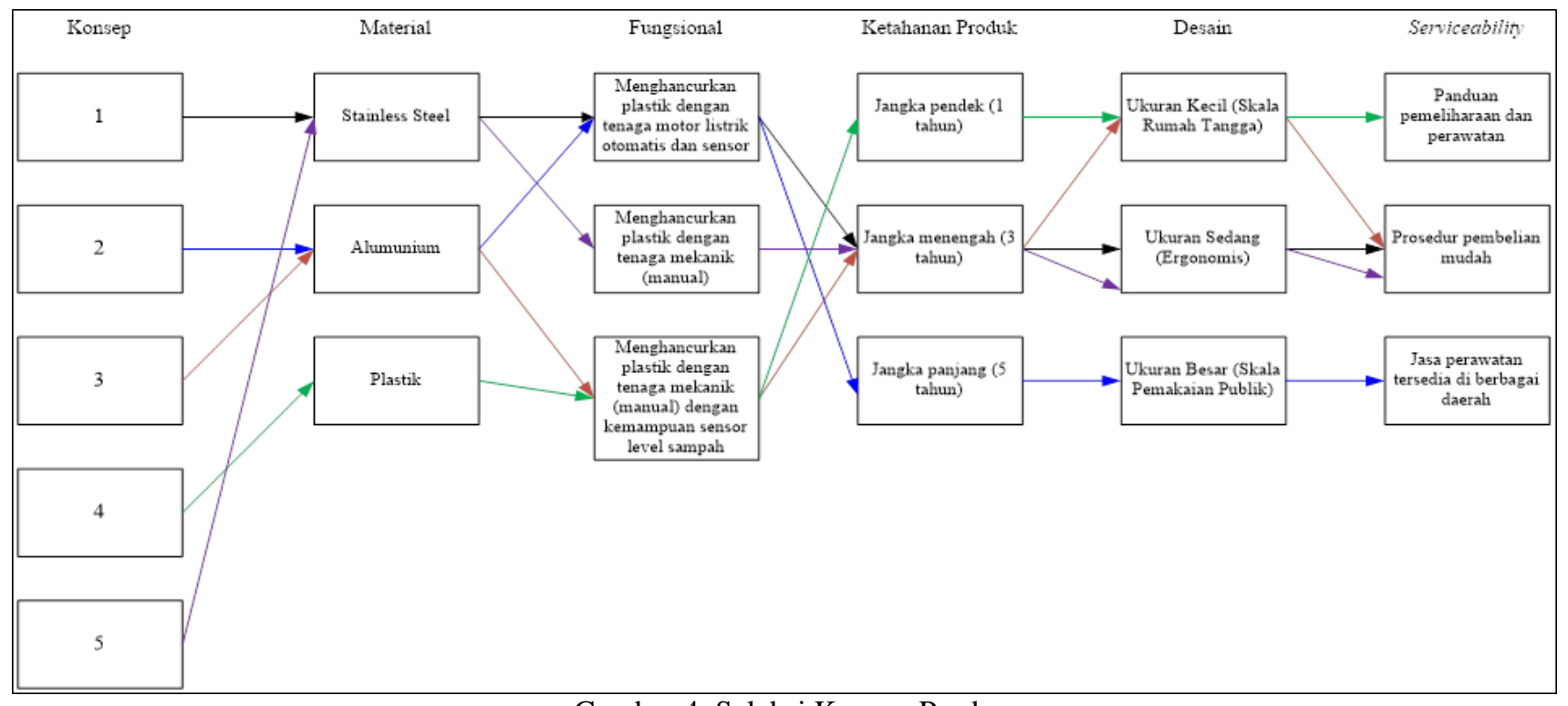

Gambar 4. Seleksi Konsep Produ

Setelah melakukan kombinasi konsep sebanyak lima konsep terhadap matriks yang digunakan. Selanjutnya dilakukan penentuan konsep terbaik untuk dikembangkan. Berdasarkan hasil penentuan konsep terbaik dengan tabel concept screening matrix (Tabel 4), dari kelima konsep diperoleh dua konsep terbaik, yaitu konsep 3 dan 5. Konsep tersebut dapat terpilih karena menghasilkan nilai akhir diatas 0 (positif) dibanding 3 konsep lainnya, yakni sebesar 3 secara berturut-turut. Maka konsep 3 dan konsep 5 dapat dilanjutkan dengan tahapan screening konsep.
Tabel 4. Concept Screening Matrix

\begin{tabular}{lccccc}
\hline \multicolumn{1}{c}{$\begin{array}{c}\text { Kriteria } \\
\text { Seleksi }\end{array}$} & $\mathbf{1}$ & $\mathbf{2}$ & $\mathbf{3}$ & $\mathbf{4}$ & $\mathbf{5}$ \\
\cline { 2 - 6 } Material & + & + & + & - & + \\
\hline Fungsional & + & 0 & 0 & 0 & + \\
\hline $\begin{array}{l}\text { Ketahanan } \\
\text { Produk }\end{array}$ & 0 & + & + & - & + \\
\hline Desain & + & 0 & 0 & + & 0 \\
\hline Serviceability & - & - & + & - & + \\
\hline Jumlah + & 3 & 2 & 3 & 1 & 4 \\
\hline Jumlah - & 1 & 1 & 0 & 3 & 1 \\
\hline Nilai Akhir & 2 & 1 & 3 & -2 & 3 \\
\hline Peringkat & 3 & 4 & 2 & 5 & 1 \\
\hline & & & & &
\end{tabular}




\begin{tabular}{cccccc}
\hline Kriteria & \multicolumn{5}{c}{ Konsep } \\
\cline { 2 - 6 } Seleksi & $\mathbf{1}$ & $\mathbf{2}$ & $\mathbf{3}$ & $\mathbf{4}$ & $\mathbf{5}$ \\
\hline Lanjutkan? & Tidak & Tidak & Ya & Tidak & Ya \\
\hline
\end{tabular}

Tahapan yang selanjutnya dilaksanakan ialah melakukan penilaian terhadap tiap kriteria seleksi berdasarkan nilai 2 orang pakar, yakni dosen Teknik Industri yang bergelut di bidang pengembangan produk dan asisten praktikum dalam mata kuliah Sistem Pengembangan Produk. Hasil pembobotan dan perhitungan dalam penilaian konsep dapat dilihat pada Tabel 5 yang mendeskripsikan scoring matrix.

Tabel 5. Scoring Matrix

\begin{tabular}{cccccc}
\hline & \multicolumn{6}{c}{ Konsep } \\
\cline { 2 - 6 } $\begin{array}{c}\text { Kriteria } \\
\text { Seleksi }\end{array}$ & Bobot & \multicolumn{3}{c}{$\mathbf{3}$} & \multicolumn{3}{c}{$\mathbf{5}$} \\
\cline { 2 - 7 } & & Rating & Nilai & Rating & Nilai \\
\hline Material & $20 \%$ & 3 & 0,6 & 3 & 0,6 \\
\hline Fungsional & $20 \%$ & 4 & 0,8 & 2 & 0,4 \\
\hline $\begin{array}{c}\text { Ketahanan } \\
\text { Produk }\end{array}$ & $30 \%$ & 3 & 0,9 & 3 & 0,9 \\
\hline Desain & $10 \%$ & 2 & 0,2 & 2 & 0,2 \\
\hline Serviceability & $20 \%$ & 2 & 0,4 & 2 & 0,4 \\
\hline Nilai Total & $100 \%$ & \multicolumn{3}{c}{2,9} & \multicolumn{5}{c}{2,5} \\
\hline Peringkat & \multicolumn{3}{c}{1} & \multicolumn{5}{c}{ Tidak } \\
\hline Lanjutkan & \multicolumn{3}{c}{ Ya }
\end{tabular}

Berdasarkan perhitungan yang didapatkan dari scoring matrix, didapatkan bahwa konsep 3 dinyatakan terpilih. Hal ini ditunjukkan dari nilai skor total yakni sebesar 2,9 yang unggul daripada konsep 5 yang hanya menghasilkan nilai total sebesar 2,5. Mengacu pada matriks pemilihan konsep dapat ditentukan bahwa konsep 3 memiliki spesifikasi sebagai berikut: tempat sampah penghancur plastik dibuat dari material alumunium, memiliki kemampuan fungsional yakni menghancurkan sampah plastik dengan tenaga mekanik/manual dan dilengkapi dengan sensor elektrik pendeteksi level ketinggian sampah, memiliki ketahanan jangka menengah (kurang lebih 3 tahun), desain berukuran kecil yang aplikatif untuk penggunaan skala rumah tangga, dan serviceability yang memungkinkan prosedur pembelian yang mudah.

\section{Arsitektur Produk}

Pada tahap ini dilakukan penyusunan skema produk yang merupakan gambaran elemen-elemen penyusun produk. Skema produk pada penelitian ini dapat dilihat pada Gambar 5.

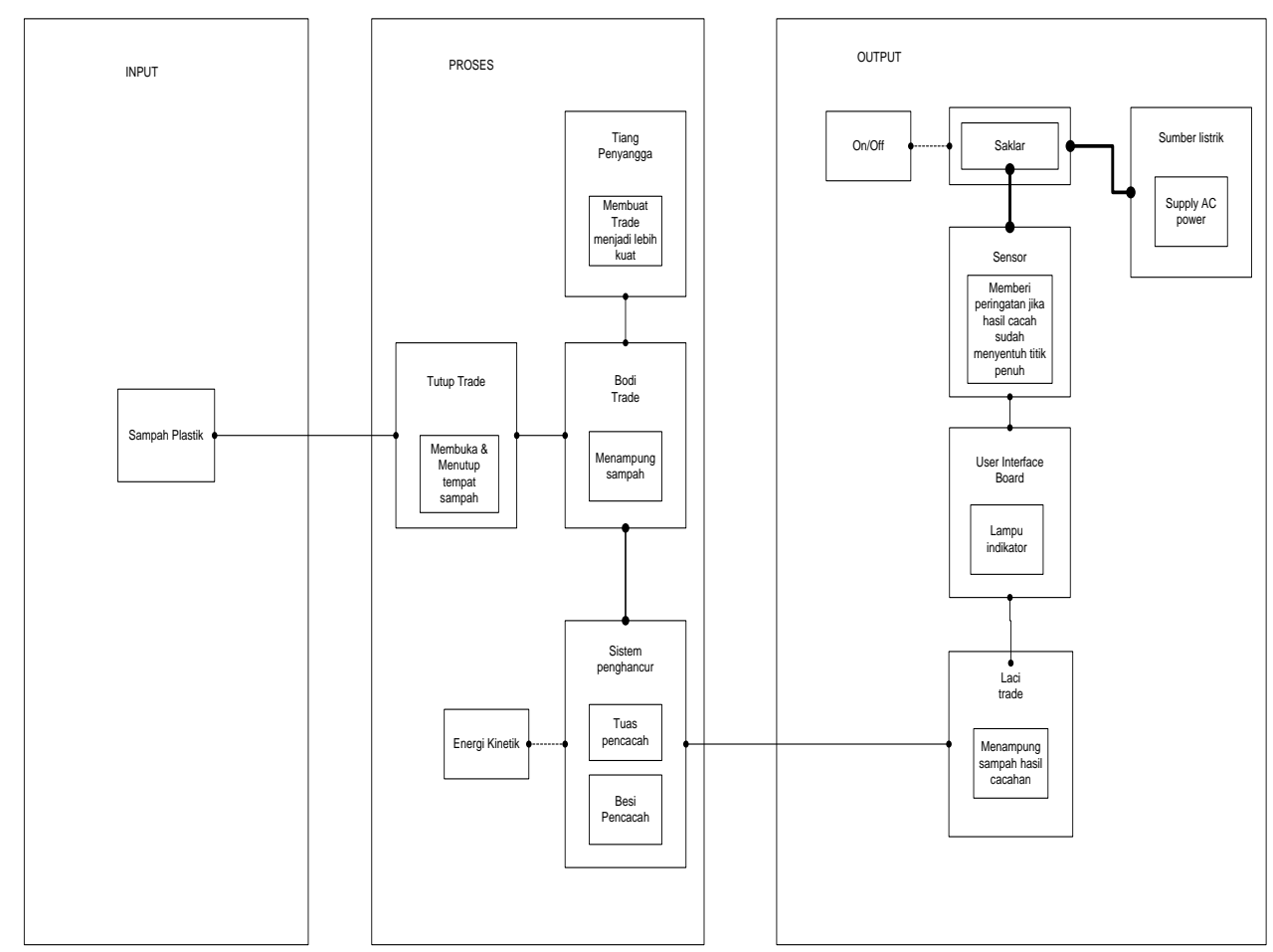

Gambar 5. Skema Produk Tempat Sampah Penghancur Plastik 
Skema Produk adalah diagram yang ada pada gambar 4 menggambarkan pengertian tim terhadap elemen-elemen penyusun produk. Skema untuk produk Trade diperlihatkan pada gambar diatas, yang memiliki elemen-elemen fisik serta aliran energi dan material. Beberapa elemen berhubungan dengan komponen-komponen kritis, seperti contohnya sensor. Namun beberapa elemen tetap diuraikan secara fungsional. Sebagai contoh, elemen fungsional "konversi energi dari energi kinetik yang berasal dari gerakan tangan untuk dikonversikan menjadi energi penghancur sampah" didesain sebagai suatu elemen yang tersentralisasi. Elemen-elemen ini juga dikelompokkan menjadi chunk, yang menghasilkan 7 chunk. Berikut adalah penjelasan mengenai chunk tersebut:

a. Integrasi Geometri dan Presisi: Penugasan elemen terhadap chunk yang sama memungkinkan satu orang atau kelompok mengontrol hubungan fisik antar-elemen. Untuk kasus Trade, akan diusulkan pengelompokkan elemen yang berhubungan dengan posisi sistem penghancur dan laci Trade

b. Pembagian Fungsi: Dari proses input-output, sistem pada produk Trade ini ialah,

1. Input: Sampah dimasukkan kedalam Trade

2. Proses: sampah akan dihancurkan menggunakan konversi energi dari energi kinetik (tangan memutar tuas pencacah sampah) menjadi energi penghancur sampah (besi pencacah)

3. Output: sampah yang telah dihancurkan, akan masuk kedalam laci kemudian jika telah penuh maka akan ada lampu sensor yang menyala (tanda sampah telah melebihi kapasitas)

c. Kemampuan (Kapabilitas) Pemasok: Tim dapat mengelompokkan elemen-elemen yang merupakan keahlian dari pemasok menjadi satu chunk. Dalam kasus Trade, tim pengembang internal melakukan sebagian besar pekerjaan desain teknik, sehingga kapabilitas pemasok tidak terlalu diperhitungkan.

d. Kesamaan desain atau teknologi produk: Adanya kesamaan desain atau teknologi produksi yang sama pada produk Trade memungkinkan penggabungan elemen elektronik pada chunk yang sama, sehingga penerapan fungsi-fungsi dapat dilakukan pada satu sirkuit saja.

e. Lokalisasi Perubahan: Untuk kasus Trade tidak dilakukan isolasi elemen pada chunk yang terpisah dalam mengantisipasi perubahan pada elemen-elemen produk

\section{Prototipe Produk}

Tahap selanjutnya adalah pembuatan desain prototipe menggunakan software Inventor dari produk Trade seperti yang ditunjukkan pada Gambar 6, 7 dan 8 .

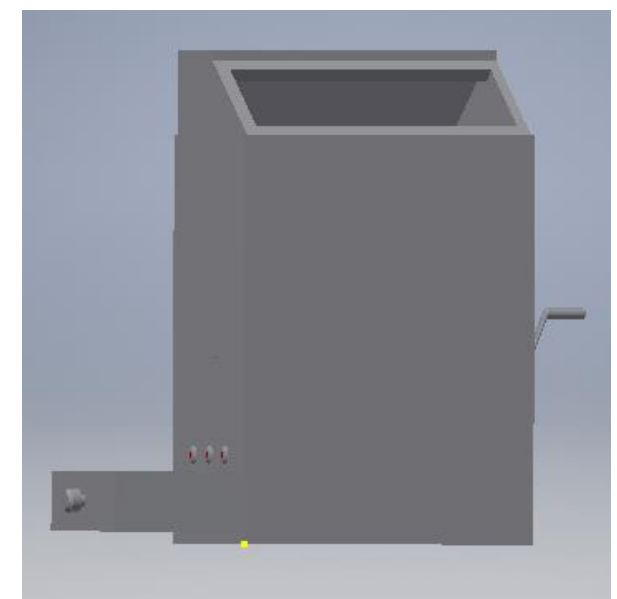

Gambar 6. Ilustrasi Desain Trade Tampak Depan

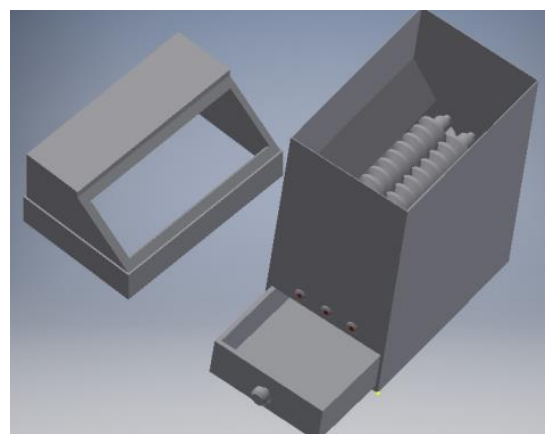

Gambar 7. Ilustrasi Desain Komponen Penyusun Trade

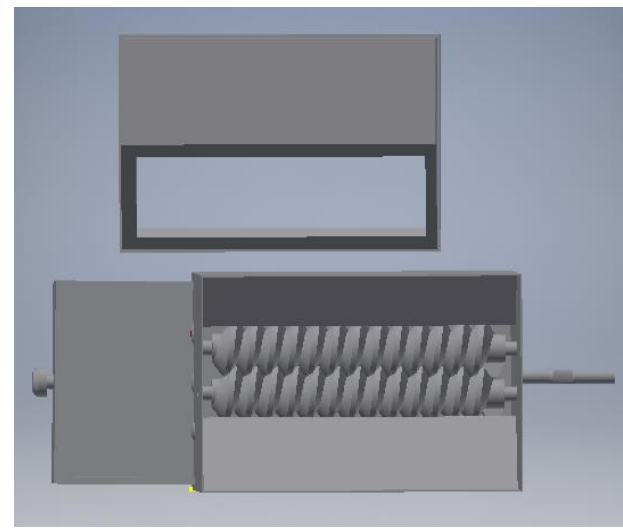

Gambar 8. Ilustrasi Desain Trade Tampak Atas

Berdasarkan hasil dari pemilihan konsep kombinasi pada produk, kemudian dilakukan gambar rancangan produk berupa sketsa yang menggambarkan produk dari berbagai tampak, yakni dari tampak depan dan tampak atas. Mengacu pada gambar 2 dan 3 dapat dilihat bahwa produk tempat sampah penghancur plastik memiliki 
beberapa bagian utama yakni, tutup/lid tempat sampah, casing body tempat sampah, laci penampung hasil cacahan sampah plastik, katup yang mendorong sampah untuk jatuh tepat pada alat penggiling sampah, alat pencacah sampah yang digerakkan secara manual (menggunakan pedal penggiling), dan sensor indikator level sampah. Dimana, dari kedua gambar tersebut dapat diketahui cara kerja dari produk tempat sampah penghancur plastik adalah sebagai berikut:

1. Sampah dimasukkan melewati tutup/lid dan akan jatuh melintasi katup tambahan yang berbentuk diagonal agar sampah langsung terperosot ke bagian alat pencacah/penghancur sampah.

2. Kemudian setelah memasukkan sampah ke tempat sampah alat penghancur sampah digerakkan secara manual, yang kemudian akan mencacah sampah plastik menjadi keping-kepingan.

3. Hasil cacahan sampah tersebut akan masuk ke dalam laci penampung untuk sementara ditampung sebelum sensor indikator sampah dapat mendeteksi sampah bila sudah mencapai ketinggian yang maksimal untuk selanjutnya cacahan sampah plastik dapat diangkut dan didaur ulang.

Setelah menyusun dan menentukan skema produk atau arsitektur dari produk, dengan beberapa elemen-elemen fungsional dari produk yang di susun menjadi kumpulan komponen (chunk) yang berbentuk fisik dengan elemen-elemen fungsional terbaik yang disusun untuk dapat menjadi bentuk fisik yang mampu berfungsi. Beberapa bagian/elemen dari produk Trade ialah tutup/lid tempat sampah, casing body tempat sampah, laci penampung hasil cacahan sampah plastik, katup yang mendorong sampah untuk jatuh tepat pada alat penggiling sampah, alat pencacah sampah yang digerakkan secara manual (menggunakan pedal penggiling), dan sensor elektrik indikator level sampah.

Pada tahapan pembuatan prototype produk alfa ( $\alpha$ ), dilakukan perangkaian tempat sampah penghancur plastik menggunakan material yang tidak sama dengan spesifikasi produk, namun ditujukan untuk mampu memiliki fungsi yang sama. Dalam penyusunan prototipe $\alpha$, digunakan material plastik dan penggiling dengan material besi yang kendalikan secara manual (menggunakan handle pemutar). Penyusunan prototipe yang telah dilakukan oleh tim pengembang produk Trade mampu berfungsi sesuai mekanisme yang diharapkan, namun mesin penggiling yang digunakan tidak cukup kuat untuk menghancurkan sampah-sampah plastik yang bersifat keras (seperti botol plastik minuman). Upaya yang dapat dilakukan dalam tahapan pengembangan produk selanjutnya ialah menggunakan mesin penggiling yang lebih tajam dan kuat, yang memiliki gerigi yang besar agar sampah plastik dapat dihancurkan secara cepat dan efisien.

\section{Analisis Ekonomi}

Pada tahapan terakhir dalam pengembangan produk, dilakukan analisis ekonomi yang bertujuan untuk menentukan harga pokok penjualan dari produk yang akan dikembangkan. Harga pokok penjualan merupakan biaya yang muncul dari barang yang diproduksi dan dijual dalam kegiatan bisnis. Berdasarkan hasil perhitungan yang ditunjukkan pada Tabel 6, dilakukan proses perhitungan dengan mempertimbangkan aspekaspek yang meliputi, biaya bahan langsung, biaya tenaga kerja langsung, penyusutan, amortiasi, begitu pula overhead pabrik, dengan nilai persediaan WIP (Work In Process) dan barang jadi tiap awalan dan akhir periode. Didapatkan hasil harga pokok penjualan sebesar Rp. 111.117.000,00 dengan mempertimbangkan semua aspek pengeluaran dalam perencanaan dan proses produksi. Sementara untuk penetapan harga jual dengan mempertimbangkan besar pajak (10\%) dan pengambilan keuntungan (20\%) didapatkan harga senilai Rp. 155.563.800,00. Selain itu, didapatkan harga pokok produksi untuk tiap unit (dalam 1 tahun) sebesar Rp. 185. 195,00 untuk jumlah output per tahunnya sebanyak 600 produk (50 unit tiap bulan). Untuk pengambilan keputusan harga jual akhir dilakukan perhitungan terhadap harga jual per unit yakni dengan menghitung rasio dari nilai hasil harga jual dengan jumlah output per tahun, didapatkan hasil pembulatan perhitungan sebesar Rp. 259.000,00 untuk tiap unit tempat sampah Trade yang akan dijual.

Tabel 6. Harga Pokok Penjualan Produk Trade

\begin{tabular}{clr}
\hline No & \multicolumn{1}{c}{ Uraian } & \multicolumn{1}{c}{ Jumlah } \\
\hline 1 & Bahan Langsung & \\
& Saklar & Rp95.000 \\
& Mesin Pencacah & Rp300.000 \\
& Sensor & Rp42.000 \\
& Casing Alumunium & Rp25.000 \\
& Pedal Penggiling & Rp110.000 \\
\hline & & Rp572.000 \\
\hline
\end{tabular}




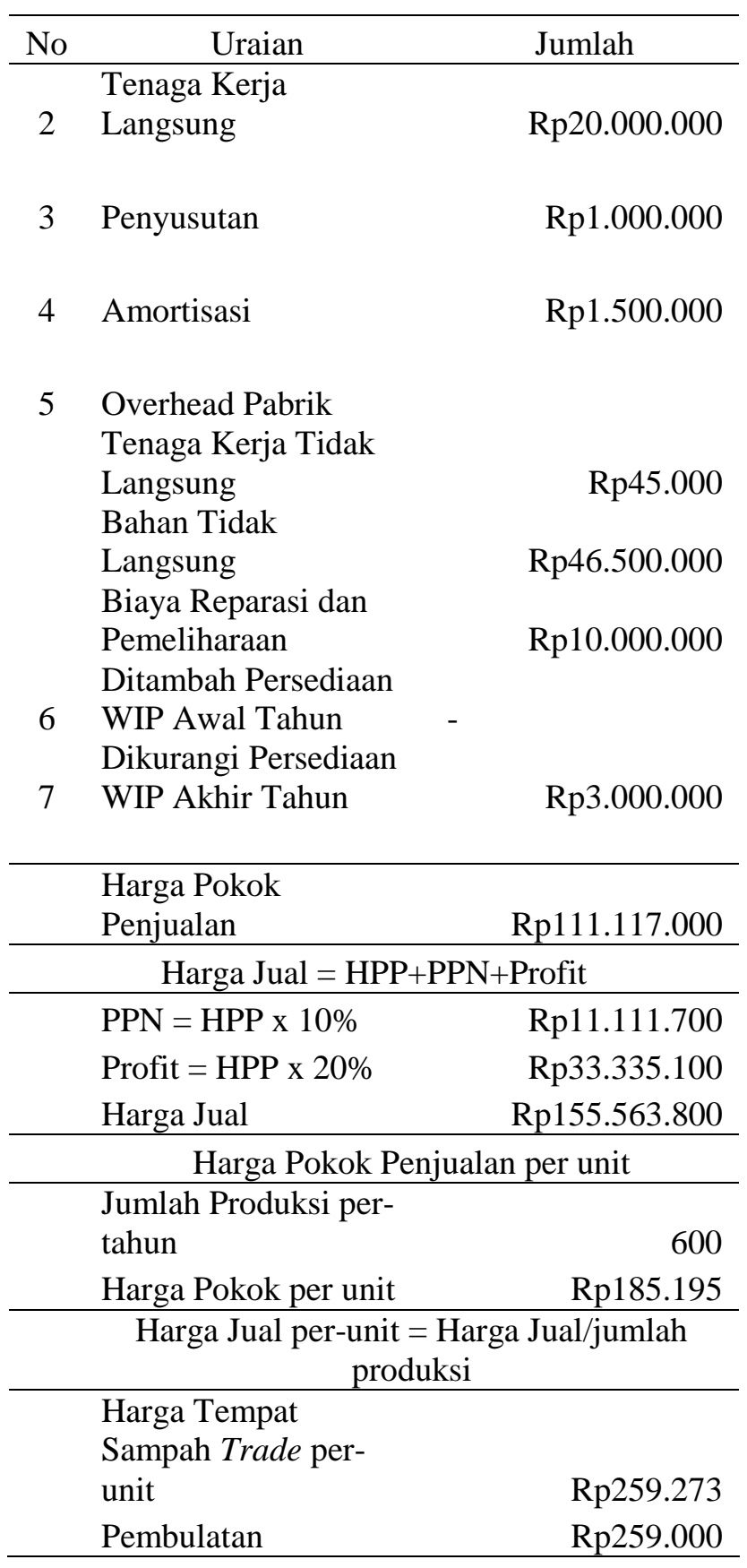

\section{KESIMPULAN}

Berdasarkan hasil pengumpulan dan pengolahan data terkait dengan perencanaan dan pengembangan produk tempat sampah penghancur plastik "Trade", maka dapat dianalisa dan ditarik kesimpulan bahwa produk yang telah dikembangkan memenuhi kebutuhan dan permintaan konsumen yakni:

1. Sesuai dengan hasil penelitian pengembangan produk tempat sampah "Trade" memiliki 2 fungsi utama yakni menghancurkan sampah plastik untuk mempermudah proses daur ulang sampah plastik, dan mampu mengindikasikan level sampah dengan sensor pada penampung agar tidak terjadi penumpukan sampah.

2. Mengacu pada perhitungan biaya produksi dan analisis ekonomi, agar produk yang dikembangkan mampu bersaing dipasaran dan menghasilkan pengembalian modal yang relatif layak untuk produksi produk tempat sampah "Trade", produk tersebut harus dijual dipasaran dengan harga yang terjangkau sebesar $\mathrm{Rp}$. 259.000,00 untuk satu unit produk dengan estimasi produksi sebesar 600 unit per tahun.

\section{DAFTAR PUSTAKA}

[1] V. Stephan \& R. D. Klassen. Extending green practices across the supply chain: The impact of upstream and downstream integration. International Journal of Operations \& Production Management, Vol. 26 Issue: 7, pp.795-821, 2006.

[2] Nasfiendry, Diktat Perencanaan dan PerancanganProduk, Jakarta: Gramedia Pustaka, 2003.

[3] K. T. Ulrich, dan S. D. Eppinger, Perancangan dan Pengembangan Produk, Jakarta: Salemba Teknika, 2001.

[4] Product Design and Development: Product Architecture.

http://staff.ui.ac.id/system/files/users/erlinda. muslim/material/12-productarc.pdf] [Diakses pada 29 Oktober 2018]

[5] Modul Praktikum Teknik Industri Universitas Al Azhar. Modul Sistem Pengembangan Produk. Jakarta: Teknik Industri. 2018 